\title{
Occurrence and distribution of Organochlorine Pesticide Residues in Water and Sediments of Earthen Fish Ponds in South Western Kenya
}

\author{
J. Nyaundi ${ }^{1, *}$, A. Getabu ${ }^{2}$, J. Onchieku ${ }^{2}$, Z. Kinaro $^{3}$, S. Bassa ${ }^{4}$, C. Nyamweya ${ }^{1}$, Hilda $\mathbf{N}^{1}$, \\ Z. Getenga ${ }^{3}$ \\ ${ }^{1}$ Kenya Marine \& Fisheries Research Institute, Kisumu, Kenya. \\ ${ }^{2}$ Faculty of Agriculture \& Natural Resource Management, Kisii University. \\ ${ }^{3}$ School of Pure \& Applied Sciences, Machakos University. \\ ${ }^{4}$ School of Spatial Planning \& Natural Resource Management, JOOUST, Bondo.
}

*Corresponding author. $\square$ 1881-40 100, Kisumu (C)+254722690268 @nyaundjo@gmail.com

\begin{abstract}
Persistent organochlorine residues in the environment are a threat to ecological health of aquatic organisms and pose a health risk to both animals and human consumers. Organochlorine pesticides were determined in water and sediments collected during wet and dry season from selected riverine and earthen fish pond sites in high altitude catchment areas within Kuja River (Kenya) between August 2016-May, 2017. Analysis of DDT and metabolites, Hexachlorocyclohexanes (HCHs) isomers and cyclodienes using a gas chromatograph (GC), and electron capture detector (ECD), confirmed using GC - Mass Spectrometry (MS). Mean ( \pm Standard error) results of DDTs, cyclodienes and $\mathrm{HCHs}$ in pond waters were:- below detection level (BDL) to $0.27 \pm 0.03 \mu \mathrm{g} / \mathrm{L}, \mathrm{BDL}$ to $0.11 \pm 0.00 \mu \mathrm{g} / \mathrm{L}$, and $4.39 \pm 1.01 \mu \mathrm{g} / \mathrm{L}$ respectively; and BDL to $0.23 \pm 0.01 \mu \mathrm{g} / \mathrm{L}, 1.20 \pm 0.005 \mu \mathrm{g} / \mathrm{L}$, and $1.71 \pm 0.02 \mu \mathrm{g} / \mathrm{L}$ in river water respectively. Sediment mean OCPs contents were significantly $(\mathrm{p}<0.05)$ higher for Dieldrin $(3.043 \pm 0.43 \mu \mathrm{g} / \mathrm{kg})$, Endrin $(2.56 \pm 0.460 \mu \mathrm{g} / \mathrm{kg})$, Heptachlor $(3.61 \pm 0.02 \mu \mathrm{g} / \mathrm{kg})$ DDT $(2.97 \pm 1.32 \mu \mathrm{g} / \mathrm{kg})$, Endosulfan $(6.31 .27 \pm 1.051 \mu \mathrm{g} / \mathrm{kg})$, Methoxychlor $(2.15 \pm$ $1.641 \mu \mathrm{g} / \mathrm{kg})$ and Lindane $(2.96 \pm 1.32 \mu \mathrm{g} / \mathrm{kg})$, respectively. A longitudinal spatial distribution pattern was noted for both water and sediment OCPs contents, demonstrating that cyclodienes are predominant contaminants in point and non-point sources in water courses. The study recommends continuous monitoring of OCPs in upstream catchment areas for informed management and policy decisions on pesticide use.
\end{abstract}

Keywords: Kuja-Migori River; Organic contaminants; Organochlorine Pesticide.

\section{Introduction}

Globally, the problem of acute pesticide poisoning has been confirmed as extensive by a variety of independent estimates. The latest estimate by a WHO task group indicates that globally there 
may be approximately over 1 million serious unintentional poisonings annually. In addition, about two million people get hospitalized for suicide attempts with pesticides (WHO, 2013). Pesticide residue is any substance in human foods or animal feeds resulting from the use of a pesticide and includes any specified derivatives such as degradation and conversion products and impurities considered to be of toxicological significance (FAO/WHO, 2002). Although pesticides have benefits, some also have drawbacks, such as potential toxicity to humans and other desired species both in terrestrial and aquatic organisms (Wandiga et al., 2002; Ezemonye et al., 2009). They are also classified the most dangerous and persistent organic chemicals known (IUPAC. 2003). Studies carried out in Egypt showed that agricultural wastes mainly pesticides, synthetic fertilizers and organic wastes released directly by underground and/or surface drained water constitute the major sources of organic and inorganic pollutants of the aquaculture fish ponds (Moustafa and Saleh, 2018).

In East Africa, organochlorine pesticides (OCPs) have been in use since the 1940s and have tended to accumulate in sediment (Werimo et al., 2009), and soil (Madadi, 2006; Ssebugere, 2010). Due to their lipophilic content, organochlorine pesticides (OCPs) in the environment are characterized by high chemical stability, poor water solubility and low vapour pressures. In addition, owing to ingestion of sediment, OC pesticides and their residues find their way into edible aquatic organisms such as fish (Ogwok et al., 2009;). Environmental concentrations and health risks associated with OCPs metabolites are well documented (Nyaundi, et al., 2019). In Kenya and across the region, available reports site gross contamination of most major river bodies across the country by discharge of industrial effluents, sewage, and agricultural waste among others. Contamination of local river bodies from pesticide use could constitute a significant environmental and health hazard, with gross implications on human health (Campbell et al., 2003; WHO, 2013).

Lake Victoria Basin economy and its catchment area is significantly derived from fisheries $(10 \%)$, agriculture (35\%), industries and mining (15\%) and the tertiary sector 40\% (GoK, 2007; Osoro et al., 2016). An overview of the agricultural activities in the catchment area indicates agriculture as being the major non-point source of pollution with regard to fertilizer and pesticide loadings to the watercourses in the study area (Musa et al., 2011; Osoro et al., 2016; Nyaundi et al., 2019). The aquaculture sub sector has the potential of contributing significantly to the national economy and supporting food security challenges hence reducing poverty as is stipulated in Kenya's Vision 2030 Economic Blueprint (GoK, 2007). However, studies have shown that pesticides have intrinsic public health and environmental risks during their production, import, use, storage and disposal (Werimo, 2009; Abong'o, 2014). With the exception of organochlorine pesticides most of which were banned from use many years ago, there are a few pesticides that will cause pollution problems in the lake region (IUPAC, 2003; Moustafa and Saleh, 2018).

A well-conserved environment gives excellent support to Kenya's Vision 2030 economic pillars and the United Nations Sustainable Development Goals. Water-borne disease risks are reported to have increased as a result of declining water quality in Lake Victoria basin wetlands (GoK, 2007). Elizabeth et al., (2011) studied the contamination of Lake Nakuru by organochlorine pesticides and found their residue levels to be very low in Tilapia graham. Kanja (1989) in studies of Kenyan mother's milk, also analysed fish samples from Rusinga Island in Lake Victoria. Mitema and Gitau, (1990) carried out an investigation on organochlorine residues in fish from Lake Victoria. They found the level of residues to be below the maximum residue limit. Mugachia et al., (1992) carried out an extensive study of organochlorine pesticide residues in fish from Lake Naivasha, Tana River at Masinga dam and the estuary of Athi (Sabaki) River at Malindi. The residue levels compared well with those reported in other studies but lindane 
levels in some samples exceeded the maximum residue limits set by WHO and FAO (Ssebugere et al., 2010).

Whereas levels of some pesticides have been documented in some basins such as the Nyando river (Getenga et al., 2004; Abong'o et al., 2014) few reports exist on pesticide levels in the highly populated areas of South Western Kenya. This investigation therefore sought to provide information on levels of OCPs in bed sediments and naturally existing surface water of tributaries of Kuja River and earthen fish ponds in the area for incidents of pesticide contamination.

\section{Materials and Methods}

\section{Study Area}

The Lake Basin region is situated between latitudes $1^{\circ} 16^{\prime} \mathrm{N}$ and $1^{\circ} 54^{\prime} \mathrm{S}$ and longitudes $33^{\circ} 55^{\prime} \mathrm{E}$ and $35^{\circ} 51^{\prime} \mathrm{E}$. This study was conducted in upstream Kuja River drainage basin in heavily populated areas of Kisii and Nyamira, and some randomly selected sites adjacent to Kericho and South Nyanza (Figure 1) counties.

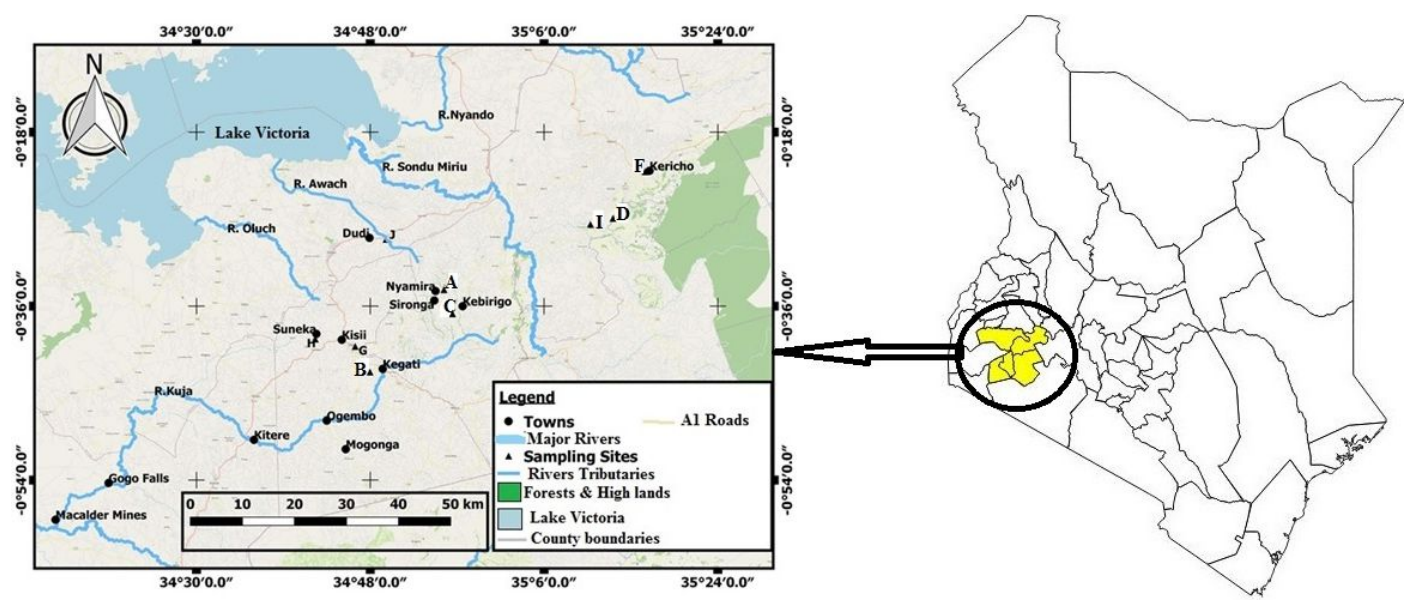

Figure 1. Map showing sampling sites in the upstream Kuja River drainage basin, Kenya.

The location of the area on which the study was carried out lies within $34^{\circ} 40^{\prime} 0$ ' $\mathrm{E}-34^{\circ} 60^{\prime}$ 5" E longitude and $0^{\circ} 24^{\prime} 04^{\prime \prime} \mathrm{S}-0^{\circ} 56^{\prime} 0$ " S latitude. The areas were selected as suitable study sites because of the large human settlements (KDHS, 2010) with intensive agro-chemical industry activities within their immediate vicinities. This area has undergone rapid ecological changes resulting from agricultural practices that have led to massive deforestation, wetlands degradation and water pollution (Abong'o 2014; Madadi et al., 2006) within the vicinity of Lake Victoria basin. Water samples were collected from stratified then randomly selected fish culture sites, and at specific selected points of streams and rivers in the counties that form part of the upper Kuja River catchment system in the Lake Victoria Basin, whose wetlands have intensively been encroached and degraded by a rapidly rising human population (Rusongoza, 2003; Osoro et al., 2016). 


\section{Sampling Sites}

Sampling was done in 8 sites, where site A, B, and C, D represented earthen ponds. Riverine sampling sites are shown as E, F, I and J (Figure 1) for nine months between August 2016 and May 2017, involving randomly selected aquaculture farms (altitude between 1500-2200m), streams and rivers. The upstream Kuja River basin is a highland zone with high potential for semi and intensive agricultural production, streams, rivers, and is densely populated $(>2,500$ persons $/ \mathrm{km}^{2}$ ) (KDHS, 2010) with undulated hills and valleys composed of clay soils suitable for water retention in pond construction at some places forested or cropped surroundings. Besides this, the volcanic loamy and clay soils in the area supports semi intensive earthen fish pond aquaculture, and this practice is capable of contributing to increased production of mainly preferred Tilapiines fish mainly O.niloticus (Range: $24.6-47.8 \mathrm{cmTL}$ ) for enhanced income and improvement of household livelihoods in the area.

\section{Sampling Design}

After stratification, purposeful sampling method was adopted. With a multi-stage sampling design (Mugenda and Mugenda, 2005), a number of wards and fish farmers were known, then $5 \%$ of each of the total was taken in order to obtain the required sample. Two divisions/wards, followed by two locations were randomly picked targeting upstream counties touching on the Kuja River drainage system. Two sub-locations followed by two ponds and rivers were randomly sampled. However, due to high correlation in fish in one pond owing to homogeneity of the prevailing aquatic environment (http://www.kisiinyamirafloodmap.net) and the target stations being in elevation between $1700-2200 \mathrm{~m}$ with tropical highland climate, only 4 samples were randomly picked from each pond and nearby river. Sampling was done weekly for the first month, biweekly for the second and third month, monthly for the fourth and fifth month and then bimonthly for the rest of the nine month study period, between August 2016-May 2017.

\section{Sample Collection}

Grab surface water samples were collected below the surface using the Van Don Sampler. Pond bottom and river sediments were collected by use of an Ekman grab sampler. Surface water in composite and bottom sediment samples were collected twice per sampling site for analysis in triplicate, both in the dry and in wet season. Grab method was randomly used in surface water sampling into $2.5 \mathrm{~L}$ amber bottles, which had been pre-washed with distilled water and dried. Each water sample was treated with $1 \mathrm{~g}$ mercuric chloride, mixed for 5 minutes to kill microorganisms so as to avoid pesticides' degradation. An Ekman grab sampler was used to obtain about $500 \mathrm{~g}$ of bottom sediment sample and immediately wrapped in aluminium foil, placed in labelled, air-tight bags; kept in ice-coolers, transported to the laboratory then kept at $-20^{\circ} \mathrm{C}$ before extraction (APHA, 2005).

\section{Sample Extraction Procedures}

Extraction and clean-up for the extraction of pesticide residues of water samples was carried out based on Solvent-phase extraction (SPE) method and according to (US EPA 2002; Getenga et al., 2004; Osoro et al., 2016). US EPA method 3540 Soxhlet extraction for the extraction of pesticide residues from sediment samples was applied (US EPA, 2002; Abong'o 2014; Osoro et al., 2016). The elute was then concentrated to $1 \mathrm{ml}$ followed by GC analysis (Kengara et al., 2010). 
Quality control and quality assurance procedures included replicate sampling, extraction and analysis for all samples. Extraction of the samples also incorporated studies of spiked samples to determine the recovery rate of the method used. The crude extracts was then concentrated at reduced pressure using a rotary evaporator to about $1.0 \mathrm{~mL}$, followed by clean-up by solid phase extraction (SPE) as described for water above. The cleaned extracts were then rotary evaporated to about $1.0 \mathrm{~mL}$, transferred into $2.0 \mathrm{~mL}$ brown vials with stoppers and then stored at $4^{\circ} \mathrm{C}$, awaiting analysis.

\section{Gas Chromatographic (GC) Analysis}

Analysis of OC Pesticides residue in water and sediment samples was carried out using Agilent 6890N gas chromatograph (equipped with an auto sampler (Agilent 7683 Series injector) and a micro-electron capture detector $(\mu \mathrm{ECD})$. The OCPs were identified by comparing their retention times with reference standards and quantified by external standard calibration and a GC-MS used for confirmation of peaks.

\section{Data Analysis}

Data was analysed using Excel spreadsheet program and results presented in form of frequency tables, bar graphs and chromatograms. Descriptive and Inferential statistics was used to statistically analyse the data collected. For level of significance, experimental (observed) data was computed to a given set value (0.05), or of Chi-square $\left(\chi^{2}\right)$. One way ANOVA statistical tool and student t-test were also used for heterogeneous data (Mugenda \& Mugenda, 2005) and thresholds compared with those of the US EPA, EPA, WHO, and NEMA standards. Analysis of variance (ANOVA) test on data obtained was done for comparisons. Single factor analysis of variance was performed for significant difference in mean concentrations.

\section{Results}

\section{Concentration of Pesticides in Water}

A total of 17 different organochlorine pesticides (OCPs), namely, metabolites of dichlorodiphenyltrichloroethane (DDT), hexachlorocyclohexanes (HCHs) isomers and cyclodiene compounds were identified (Table $1 \& 2$ ), in both surface water and bed sediment samples during the survey.

Table 1. Profile of Hexachlorocyclohexanes (HCHs) \& Dichlorodiphenyltrichloroethane (DDT) mean levels in surface water/bed sediment $(\mu \mathrm{g} / \mathrm{L} ; \mu \mathrm{g} / \mathrm{kg}) \pm \mathrm{SE}$ in Kuja River drainage basin. (n $=56)$

\begin{tabular}{lllll}
\hline SN & HCHs & Conc. levels & DDTs & Conc. levels \\
\hline 1 & $\alpha-\mathrm{HCH}$ & $0.01 \pm 0.002 / 1.4 \pm 0.42$ & $\mathrm{p}, \mathrm{p}$-DDE & $0.025 \pm 0.00 / 1.874 \pm 0.42$ \\
2 & $\beta-\mathrm{HCH}$ & $0.02 \pm 0.0 / 0.94 \pm 0.34$ & $\mathrm{p}, \mathrm{p}$ '-DDD & $0.032 \pm 0.01 / 1.115 \pm 0.03$ \\
3 & $\gamma-\mathrm{HCH}$ & $0.26 \pm 0.05 / 1.13 \pm 0.31$ & $\mathrm{p}, \mathrm{p}$ '-DDT & $0.21 \pm 0.08 / 1.598 \pm 0.05$ \\
4 & $\delta$ - $\mathrm{HCH}$ & $0.01 \pm 0.00 / 1.9 \pm 0.26$ & & \\
\hline
\end{tabular}


Table 2. Profile of Cyclodienes group mean levels in surface water, bottom sediments ( $\mu \mathrm{g} / \mathrm{L}$; $\mu \mathrm{g} / \mathrm{kg}) \pm$ SE in Kuja River drainage basin. $(\mathrm{n}=74)$

\begin{tabular}{llcc}
\hline SN & Compound & $\begin{array}{c}\text { Conc. Level in water } \\
(\mu \mathrm{g} / \mathrm{L})\end{array}$ & $\begin{array}{c}\text { Conc. Level in sediment } \\
(\mu \mathrm{g} / \mathrm{kg})\end{array}$ \\
\hline 1 & Aldrin & $0.015 \pm 0.02$ & $2.456 \pm 0.41$ \\
2 & Dieldrin & $0.021 \pm 0.01$ & $3.871 \pm 0.68$ \\
3 & Endrin & $0.044 \pm 0.02$ & $2.984 \pm 0.16$ \\
4 & Endrin aldehyde & $0.043 \pm 0.01$ & $2.575 \pm 0.28$ \\
5 & Endosulfan I & $0.013 \pm 0.03$ & $3.525 \pm 0.32$ \\
6 & Endosulfan II & $0.043 \pm 0.02$ & $5.529 \pm 0.89$ \\
7 & Endosulfan sulfate & $0.411 \pm 0.06$ & $7.986 \pm 0.90$ \\
8 & Heptachlor & $0.005 \pm 0.01$ & $2.633 \pm 0.26$ \\
9 & Heptachlor epoxide & $0.018 \pm 0.03$ & $3.277 \pm 0.37$ \\
10 & Methoxychlor & $0.369 \pm 0.08$ & $1.027 \pm 0.35$ \\
\hline
\end{tabular}




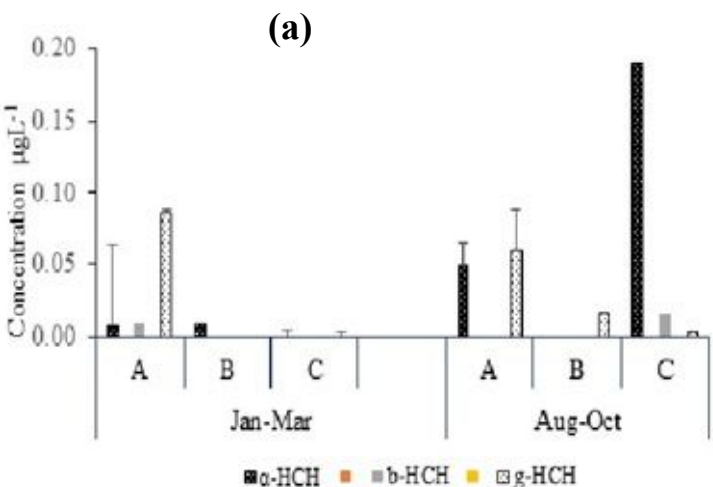

(b)

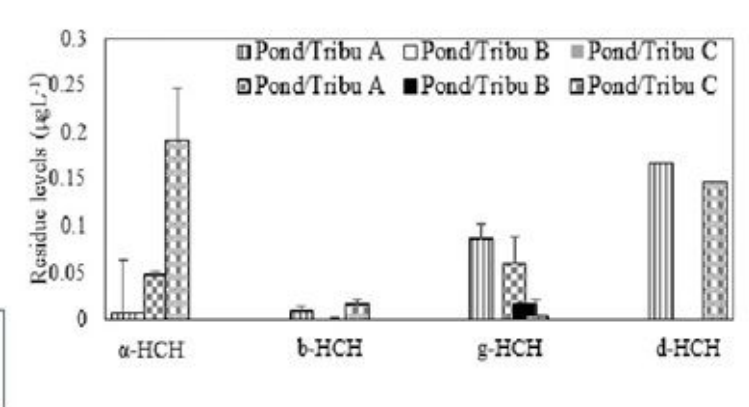

Figure 2. (a) Mean ( \pm standard error) seasonal variations of $\mathrm{HCH}$ pesticide residue levels in water samples ( $\mu \mathrm{g} / \mathrm{L})$ in sampled sites in Kuja River drainage basin, and (b) Mean ( \pm standard error) $\mathrm{HCH}$ pesticide residue levels in water samples $(\mu \mathrm{g} / \mathrm{L})$ in sampled sites in Kuja River drainage basin.

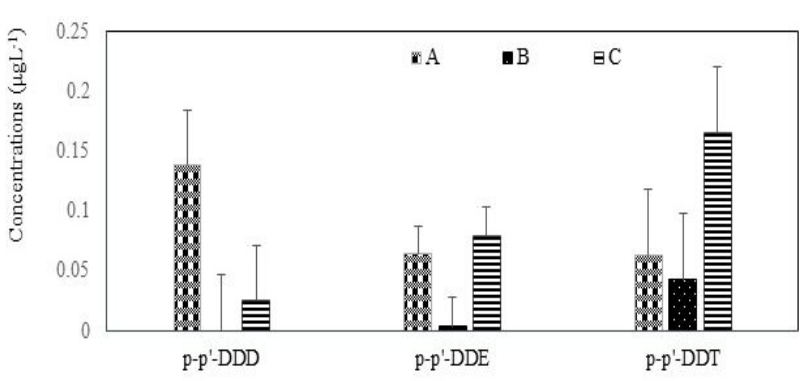

(a)

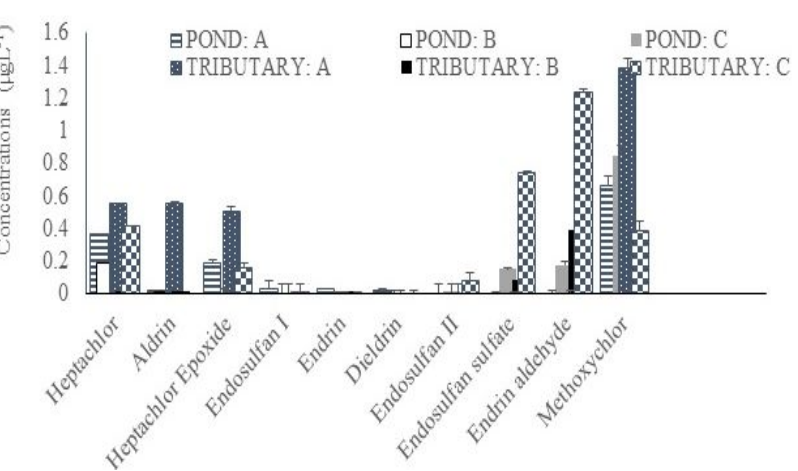

(b)

Figure 3. (a) Mean ( \pm standard error) $\mathrm{HCH}$ pesticide residue levels in water samples $(\mu \mathrm{g} / \mathrm{L})$ in sampled sites in Kuja River drainage basin, (b) Profile of means ( \pm standard error) of selected OCPs concentrations in surface water samples from Kuja River catchment, Kenya, 2016. 


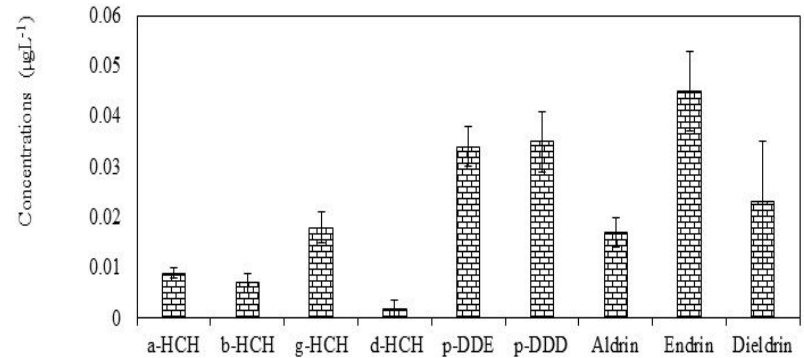

(a)

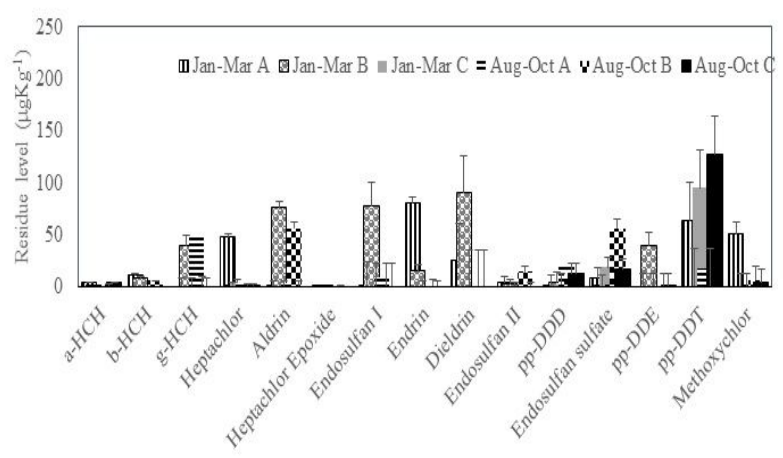

(b)

Figure 4. (a) Profiles of means ( \pm standard error) of selected OCPs concentrations in surface water samples from Kuja River catchment, Kenya, 2016 (b) Profiles of means ( \pm standard error) seasonal variation of OCPs concentrations $(\mu \mathrm{g} / \mathrm{Kg})$ in bottom sediment samples from upstream Kuja River drainage system, Kenya. 


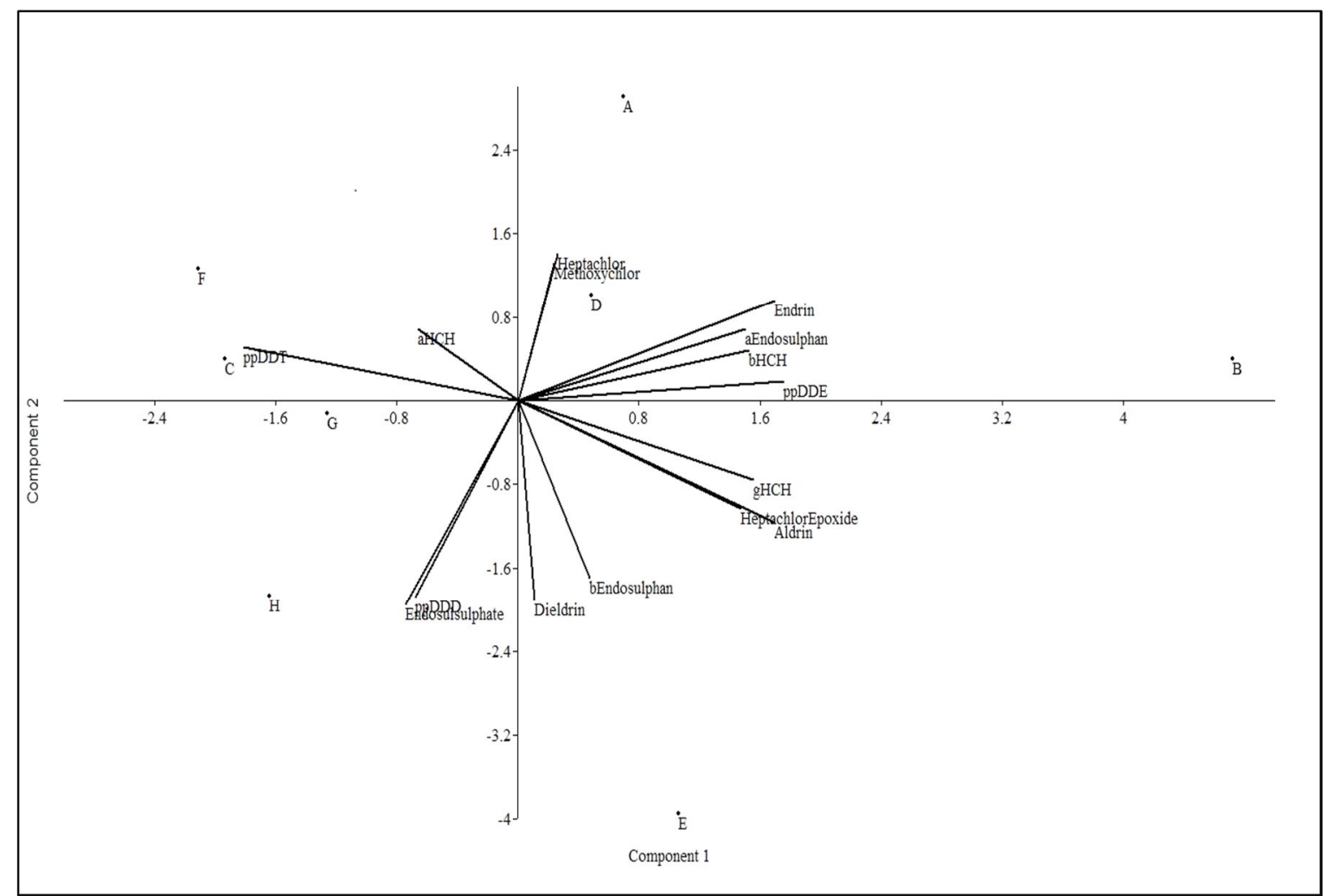

Figure 5. PCA scatter diagram (Agglomerative) showing variations of sampling stations according to concentration of organochlorine pesticide (OCPs) residues in sediment from selected earthen fish ponds and streams, upstream Kuja River drainage system, 2016/2017. 
For easier identification, the pesticides were presented in three groups namely, the HCHs, DDTs and cyclodienes, with DDTs and its metabolites having a high overall mean concentration of $0.06 \pm 0.004 \mu \mathrm{g} / \mathrm{L}$ in surface earthen pond water (Figure $3 \mathrm{a}$ ). In general, the OCPs residue levels in sediments were much higher than those in surface water, for instance the mean residue level for DDE and DDT in bed sediment was $1.874 \pm 0.42$ and $1.598 \pm 0.05$, respectively (Figure $4 \mathrm{~b})$. Similarly, Lindane $(\gamma-\mathrm{HCH})$ residue mean levels were higher in surface water $(0.026 \pm 0.005 \mu \mathrm{g} / \mathrm{L})$ (Figure $2 \mathrm{a} \& \mathrm{~b}$ ), with notable spatial and seasonal variations of the $\mathrm{HCH}$ levels in surface water. It was only the cyclodienes Endosulfan and Methoxychlor that exhibited a significant seasonal difference (ANOVA: $p=0.002(p<0.05)$ ). About $25 \%$ of the pesticide (OCPs) levels in surface water were ranging from below detection limit (BDL) to levels close to $0.2 \mu \mathrm{g} / \mathrm{L}$ in both sampling sites A, B and C. All the OCPs residue levels analysed, especially the four $\mathrm{HCH}$ isomers, lay in the range of BDL $-7.896 \mu \mathrm{g} / \mathrm{L}$ in both water and sediment (Figure 2 a \& b). Overall, HCHs (45\%) and its isomers were the most dominant pesticides recorded in surface water samples. The concentration of pesticide residues was not statistically significant between stations (ANOVA: $\left.\mathrm{p}=0.219(\mathrm{p}>0.05), \mathrm{F}_{\text {crit }}=2.31\right)$ ) during the dry season but varied significantly among sites along the catchment system (ANOVA: $p<0.05$ ), when compared with the wet season.

The mean concentrations for few other selected cyclodiene compounds such as Endosulfan $0.23 \pm 0.032 \mu \mathrm{g} / \mathrm{L})$, Methoxychlor $(0.37 \pm 0.121 \mu \mathrm{g} / \mathrm{L})$ and Aldrin $(0.4 \pm 0.244 \mu \mathrm{g} / \mathrm{L})$ in surface water were, however, not significantly higher (ANOVA: $\mathrm{p}=0.219(\mathrm{p}>0.05))$ between different sampling stations (Figure 3 a \& b), probably be due to homogeneity of the aquatic environment in the study area. It was observed that there was no statistical significant difference (ANOVA: $\mathrm{p}=0.716(\mathrm{p}>0.05)$, in the concentrations of these compounds, in all stations sampled. There was no statistical significant difference observed between sampled stations (ANOVA: $\mathrm{p}=$ $0.312,(\mathrm{p}>0.05))$.

Mean Endosulfan sulphate residue was in the range of $0.52-4.62 \mu \mathrm{g} / \mathrm{L}$ with greatest and least values being recorded in Pond C $(0.19 \pm 0.121 \mu \mathrm{g} / \mathrm{L})$ and tributary $\mathrm{J}(0.50 \pm 0.121 \mu \mathrm{g} / \mathrm{L})$ respectively (Figure $3 \mathrm{~b}$ ). Endosulfan sulphate is the major degradation product of technical Endosulfan which is a mixture of two isomers $(\alpha \& \beta)$ in the ratio of 7:3.

\section{Concentration of Pesticides in Sediments}

Among the metabolites, $p$, $p$ '-DDT recorded the highest frequency of detection $(33 \%)$, followed by $p, p$-DDE $(22 \%)$ and $p, p$ '-DDD (19\%). Other broken down metabolites of DDT were in most cases detected but in low concentrations, with $p, p^{\prime}$-DDE being detected with a frequency of $3.75 \%$ only in Pond A as well as tributary sampling site E (Figure 4 b). However, it was noted that there was a statistical significant difference in mean metabolite values between seasons but not between stations (ANOVA: $p=0.003,(p<0.05)$ ). Although no statistical significant difference was recorded between Endosulfan I and Heptachlor epoxide among site variations (ANOVA: $\mathrm{p}=0.282$ ( $\mathrm{p}>0.05$ ), Endosulfan I at site Pond A during Jan-Mar 2017 sampling, having recorded highest mean levels of $3.531 \pm 0.50 \mu \mathrm{g} / \mathrm{kg}$ (Figure $4 \mathrm{~b}$ ). Sediment residue levels in the wet period were observed to be with $2.7 \pm 0.02 \mu \mathrm{g} / \mathrm{kg}$ as observed mean.

Mean OCPs concentrations in sediment samples ranged between $0.94 \pm 0.34 \mu \mathrm{g} / \mathrm{kg}$ to $7.9 \pm 0.09 \mu \mathrm{g} / \mathrm{kg}$ when all sampling stations during the survey are compared with an overall mean of $1.53 \pm 0.47 \mu \mathrm{g} / \mathrm{kg}$ in bottom sediment respectively. It was observed that $\delta$-HCH recorded the highest mean concentration $(1.9 \pm 0.26 \mu \mathrm{g} / \mathrm{kg}$ ) among the $\mathrm{HCH}$ isomers while Endosulfan sulphate $(39 \%)$ and DDT were the predominant pesticide in sediment (Table $1 \& 2$, Figure 4 
b). There was no significant difference in bottom sediment sample means between the dry and wet period.

\section{Discussion}

According to prevailing local guidelines (NEMA, 2000; GoK, 2007) and threshold set by US EPA, the values obtained in this study are within the values recommended of $0.05 \mu \mathrm{g} / \mathrm{L}$ and 2.0 $\mu \mathrm{g} / \mathrm{L}$ for natural drinking waters, except for $\gamma-\mathrm{HCH}$ in this study. Though $\gamma-\mathrm{HCH}$ isomer concentrations are higher than maximum acceptable standards set by US EPA (IUPAC, 2003), these results are lower than maximum thresholds set by $\mathrm{WHO}$, of $2.0 \mu \mathrm{g} / \mathrm{L}$ in drinking water. Presence of pesticides residues in samples analysed is indicative that the various anthropogenic activities in the study area such as rapid urbanization, horticultural farms, small holder coffee and tea farms and upcoming food processing industries in the study area may be a contributory factor in incidences of environmental organic contamination (Kiremire, 1997; Mbabazi, 1998; Abong'o et al., 2014), due to probably, semi-intensive agricultural practices in the study area..

Aldrin, and Dieldrin pesticide residue concentrations in this study were higher than recommended guideline value for pesticides residues in fresh water bodies set by WHO of $0.03 \mu \mathrm{g} / \mathrm{L}$ (Wandiga et al. (2002; Hamilton et al., 2003). Both isomeric Endosulfans recorded higher values in the wet seasons than in the dry seasons. This is indicative of active farming season and possible accumulations during run offs from seasonal heavy rains experienced in the area. . It is known that $\not, p$-DDT is the principal isomer of technical DDT, although its structure permits the formation of several different isomeric forms. When both samples are compared, the residue levels detected in bottom sediments were in the range $(0.94 \pm 0.34$ $7.9 \pm 0.91 \mu \mathrm{g} / \mathrm{kg})$, higher than those detected in surface water $(0.01 \pm 0.002-0.41 \pm 0.06 \mu \mathrm{g} / \mathrm{kg})$ implying that bottom sediments have high pesticide capture efficiency than surface water in the target area. Although all the selected pesticides were detected in bottom sediment samples within tributaries of upstream Kuja River drainage basin (Table1 \& 2), they exhibited less variations in content when compared to levels for surface water. It was also observed in this study that the concentration of pesticide residues in sediment samples were relatively higher during the wet season as compared with the dry season, differences could be attributed to runoffs experienced during this period. Results from this study indicate that tributary D, I, J as well as Pond $\mathrm{C}$ all exhibited values that were above the level for natural drinking water, at $0.50,0.77$ and $0.19 \mu \mathrm{g} / \mathrm{L}$ respectively (IUPAC, 2003). It is worthwhile to note that probably due to the hydrophobic nature of pesticides, the sediment samples recorded higher mean values (Ezemonye et al., 2009; Abong'o, 2014; Hamilton, et al., 2003). This is also attributed to the fact that bottom sediment acted as sinks such that fairly higher residues were recorded in them during this study.

PCA scatter diagram observations (Figure 5) show Dieldrin which is an epoxide of Aldrin having an increased reaction due to changes caused probably by factors in the environment such as weather and micro species. Station A and B show more of cyclodienes and $\mathrm{HCH}$ isomers correlated together in water column in study area. This is articulated by mean residue variations (Table 2) and the observed characterization of the compounds. The $\alpha-\mathrm{HCH}, \beta-\mathrm{HCH}$ and $\gamma$-HCH isomers dissipate in nature after effect from sunlight and bacteria hence are closely related.

World Health Organization (WHO) and US EPA agencies have not classified Endosulfan

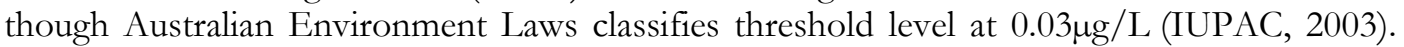


Though Endosulfan results in bed sediment is higher than recommended standards, Endosulfan I residue level is lower in water samples but not for Endosulfan II which was slightly higher, at $0.04 \mu \mathrm{g} / \mathrm{L}$. These differences could be due to lipophilic nature of pesticides in biota.

\section{Conclusion and Recommendation}

Levels of OCPs in sediments were much higher than those in water, with mean levels of $\mathrm{HCH}$ isomers, DDT and its metabolites in river and pond surface water below the WHO recommended levels for drinking water. However, Aldrin and Heptachlor in water were above these limits. Dieldrin, endrin, lindane pp-DDT, pp-DDD and pp-DDE in sediments appear higher than the threshold effect level (TEC) for freshwater sediments quality guideline values. The results imply that pesticide contamination in water and sediments exist in River Kuja drainage basin, indicating that anthropogenic activities such as urbanization, industrial and agricultural practices could be contributing to the residue levels observed in this study, hence, providing evidence of potential risk to aquatic organisms and the environment in general. Since there are no previously documented data on OCPs, the present study can serve as a reference point for future studies. The study area lies within the high altitude agriculture and aquaculture potential areas of the catchment of Lake Victoria basin (Kenya), where the landscape may promote increased erosional loss of soil; and transfer of pesticide residues to surface waters downstream and into Lake Victoria ecosystem. We therefore recommend enhanced awareness on safety and efficient use of agrochemicals; and regular monitoring of water, fish and crop products in order to capture persistence and dissipation of OCPs in existing natural waters and along food chains so as to reduce potential health risks from long-term exposure to toxic pesticides residues.

\section{Conflict of Interest}

The authors declare that they do not have any competing interests.

\section{Acknowledgement}

The authors wish to express their appreciation to the National Council Science Technology and innovation (NACOSTI) for the grant award, and Kenya Marine and Fisheries Research Institute (KMFRI) Director, for partial support and travel grants. We also wish to thank all those who provided guidance and reviewed the manuscript.

\section{References}

Abong'o, D.A., Wandiga, S.O. and Jumba, I.O. (2014). Occurrence and distribution of organochlorine pesticide residue levels in water, sediment and aquatic weeds in the Nyando River catchment, Lake Victoria, Kenya. Afr. J. Aqua. Sci. 43: 255-270. 
APHA (American Public Health Association) (2005). Standard Methods for the Examination of $W$ ater and Wastewater (Vol. 21). Washington, DC. pp. 75 - 89

Campbell, L.M., Hecky, R.E., Nyaundi, J.K., Muggide, R. and Dixon, D.G. (2003). Distribution and Food-Web Transfer of Mercury in Napoleon and Winam Gulfs, Lake Victoria, East Africa. J. Great Lakes Res. 29 (Sup.2), 267-282.

Elizabeth, W.N., Mucai, M. \& Ngugi, C. (2011). Zooplankton partitioning in a tropical alkalinesaline endorheic Lake Nakuru, Kenya: Spatial and temporal trends in relation to the environment. Lakes \& Reserv Res \& Mngt 16(1), 35-47.

Ezemonye, L.I., Ogbeide, O., Tongo, I., Ogbomida, E., Enuneku, A.A. and Ogbomida E. (2009). Pesticide contaminants in Clarias gariepinus and Tilapia zilli from three rivers in Edo State, Nigeria; Implications for Human Exposure. International Journal of Food Contamination. 2:3. 4-10.

Food and Agricultural Organization of United Nations, FAO/WHO. (2002). Pesticides Residues in food-1994 Report of Joint Meeting of FAO Panel of Experts on Pesticide Residues in Food and the Environment and WHO Toxicological and Environmental Core Assessment Groups (FAO plant production and protection Paper 127).

Getenga, Z.M; Kengara, F.O. and Wandiga, S.O. (2004). Determination of organochlorinc pesticides in soil and water from River Nyando Drainage system within Lake Victoria Basin, Kenya. Bull. Environ. Contam. Toxicol 72(2): 335-342.

Government of Kenya, GoK. (2007). National Economic \& Social Council of Kenya (NESCK). Kenya Vision 2030. Government Printers, Nairobi, Kenya.

Hamilton, D.J., Ambrus, Á., Dieterle, R.M., Felsot, A.S., Harris, C.A., Holland, P.T., and Zeeh, B. W. (2003). Regulatory limits for pesticide residues in water (IUPAC Technical report). Pure and Applied Chemistry 75(8): 1123-1155.

International Union of Pure \& Applied Chemistry, IUPAC. (2003). Regulatory Limits For Pesticides Residues in Water. Pure and Applied Chemistry 75: 1125-1156.

Kanja, L.W. (1989). Organochlorine pesticides in Kenyan mothers milk: Levels and sources Ph.D. dissertation. University of Nairobi. Nairobi. Kenya: pp. 174.

Kenya Demographic \& Health Survey, KDHS. Kenya National Bureau of Statistics (KNBS) and ICF Macro. 2010. Calverton, Maryland: KNBS and ICF Macro.

Kengara, F.O., Schramm, K-W., Doerfler, U., Munch, J.C., Henkelman, B., Welzl, G., Silke, B., Hense, B. and Schroll, R. (2010). Degradation capacity of a 1, 2, 4-trichlorobenzene mineralizing microbial community for traces of organochlorine pesticides, Sci Total Environ, 408: 3359-3366.

Kiremire. B.T. (1997). The status of Chemicals in Uganda and a Survey of Disposal Methods. Paper presented at Lake View Hotel, Mbarara, February 1997. pp. 20-28.

Madadi, O.V., Wandiga S.O. and Jumba, I.O. (2006). The status of persistent organic pollutants in Lake Victoria catchment. In: Odada, Eric O., Daniel, O. (Eds.). Proceedings of the 11th World Lakes Conference 2: 107-112.

Mbabazi, S.B. (1998). Levels of lindane in soil plants and selected soil fauna in a sprayed maize agro ecosystem: M.Sc. Thesis, Makerere University, Kampala, Uganda.

Mitema, E.S. and Gitau, F.K. (1990). Organochlorine residues in fish from Lake Victoria, Kenya. Africa J. Ecol. 28(3): 234-239.

Mugachia, J.C., Kanja, J. and Maitho, T.E. (1992). Organochlorine pesticides in estuarine fish from the Athi River, Kenya. Bull Environ. Contam. Toxicol. 49(2), 199-206.

Mugenda, O.M. and Mugenda A.G. (2005). Research Methods: Quantitative and Qualitative Approaches. (2nd ed). African Centre for Technology Studies. Nairobi, Kenya. 
Moustafa, M. and Saleh, A. (2018). Water and Fish Quality of Aquaculture Pond Adjacent to Intensive Pesticides application Agro-System. Fish Aqua J 2018, 9:3

Musa, S., Gichuki, J.W., Raburu, P.O. and Aura, C.M. (2011). Organochlorine and organophosphorus pesticide residues in water and sediment from Yala/Nzoia River within Lake Victoria Basin, Kenya, J Ecol Nat Env. 3(12): 392-399.

National Environment Management Authority, Uganda, (NEMA), (2000). Status of Persistent Organic Pollutant Pesticides in Uganda: A Historical Overview. NEMA Secretariat, Kampala. Nyaundi, J.K., Getabu, A.M., Kengara, F., Onchieku, J., Njiru, M. and Kinaro, Z.O. (2019). Assessment of organochlorine pesticides (OCPs) contamination in relation to physicochemical parameters in the upper river Kuja catchment, Kenya (East Africa). Int J F \& Aqua. 7(1): 172-179.

Ogwok, P., Muyonga, J.H. and Sserunjogi, M.L. (2009). Pesticide residues and heavy metals in Lake Victoria Nile perch, Lates niloticus, belly flap oil. Bull. Env. Cont. Tox. 82: 529-533.

Osoro, E.M., Wandiga S.O., Abong'o, D.A., Madadi, V.O. and Macharia, J.W. (2016). Organochlorine pesticides residues in water and sediment from Rusinga Island, Lake Victoria, Kenya. Journal of Applied Chemistry, 9(9): 56-63.

Pests Control Products Board, PCPB. (2008). Records on annual import statistics of various pesticides imported to Kenya, Government Press, Nairobi, Kenya.

Rusongoza, P.K. (2003). Urban disaster mitigation and environmental impact assessment of urbanization in Uganda. In: New Technologies for Urban Safety of Mega Cities in Asia, Tokyo 371-372.

Soto, A.M., Chung K.L. and Sonnen Schein, C. (1994). "The pesticides endosulfan, toxaphene, and dieldrin have estrogenic effects on human estrogen-sensitive cells." Env Heal Per 102(4): 380-383.

Ssebugere, P., Wasswa, J., Mbabazi, J., Nyanzi, S., Kiremire, B. and Marco, J. (2010). Organochlorine pesticides in soils from South-Western Uganda. J. Chemosphere 78(10):12501255.

Wandiga, S.O., Yugi, P.0., Barasa, M.W., Jumba, I. O. and Lalah, J.O. (2002). The distribution of organochlorine pesticides in marine samples along the Indian Ocean coast of Kenya. Environmental Toxicology 23: 1235-1246.

Werimo, K., Bergwerff, A.A. and Seinen, W. (2009). Residue levels of organochlorines and organophosphates in water, fish and sediments from Lake Victoria - Kenyan portion. Aquat. Ecosyst. Health Manag. 12: 337-341.

World Health Organization, WHO. (2013). Guidelines and International Standards for Drinking Water Quality, ACQWS Paper No. 3.World Health Organization. (2005), the WHO Recommended Classification of Pesticides by Hazard. 